\title{
ASAL-USUL REOG: SASTRA LISAN SINDIRAN BIROKRASI PADA MASANYA
}

\author{
Siwi Tri Purnani \\ Universitas Negeri Malang, siwitri_purnani@yahoo.com
}

\begin{abstract}
Literature is one form of cultural for delivering all forms of initiative, work, events, and human beliefs are poured in written and non-written. Literary were created also to be used for the various purposes that people wants, to give suggestions, satire, criticism, education, and so on. This article aims to let the reader understand that one of the examples of oral literature that was also created with the sarcasm is the story of the origin of Reog. There is one version that spread in the many peopleand has links with the political bureaucracy of its time. At that time, Reog believed to be used as a medium or a means to convey satire and criticism of the people to the government. The sarcasm is contained in Reog's origins with a version of the story of $\mathrm{Ki}$ Ageng Kutu's rebellion, a royal servant in the Bhre Kertabhumi period, the last Majapahit king who had a power in the fifteenth century. It was told that Ki Ageng Kutu was wrathful with the influence of King's wife who came from Cina and his corrupt government.
\end{abstract}

Keywords: origin's of Reog, oral literature, satire

\section{PENDAHULUAN}

Awal mula perkembangan sastra dimulai dari sastra lisan lalu ke sastra tulisan karena manusia terlebih dahulu mengenal lisan daripada tulisan. Akan tetapi, keberadaan sastra lisan semakin lama semakin tidak dikenal karena penyebarannya yang dilakukan melalui lisan. Padahal sastra lisan tersebut memiliki keistimewaan tersendiri dibandingkan dengan sastra tulis. Masyarakat Indonesia menghadapi dua fenomena budaya yang saling berdampingan dan bersinggungan, yakni kebudayaan lisan dan kebudayaan tulisan (Taum, 2011:1). 
Kebudayaan kesusastraan lisan-tradisional adalah kebudayaan yang dituturkan dengan cara lisan, sedangkan kebudayaan kesusastraan tulisan adalah kebudayaan yang dituturkan dengan tulisan. Namun, kedua jenis kebudayaan tersebut juga saling berdampingan dan terkadang berkaitan satu sama lain. Pada jaman dahulu, saat budaya lisan mendominasi, bukan berarti bahwa budaya tulisan tidak ada, tetapi fenomena budaya tulisan sangat sedikit. Hal ini dikarenakan saat itu banyak manusia yang masih buta aksara. Sebaliknya, ketika fenomena budaya tulisan mendominasi, budaya lisan tidak hilang, tapi termarjinalkan. Termarjinalkannya budaya lisan karena banyak kalangan beranggapan bahwa kebudayaan lisan adalah sesuatu yang primitif. Padahal banyak nilai-nilai budaya yang terkandung dalam sastra lisan yang tidak diperhatikan.

\section{PEMBAHASAN}

\section{Asal-usul Reog Ponorogo Sebagai Salah Satu Sastra Lisan}

Karya sastra adalah ungkapan pikiran dan perasaan seorang sastrawan saat ingin menuangkan perasaan maupun fakta kejadian-kejadian yang ada di sekitarnya, baik yang dialaminya maupun yang terjadi pada orang lain. Dalam perkembangannya, sastra tidak hanya berbentuk tulisan sebagaimana banyak dipelajari dan ditemui pada literatur-tekstual, tetapi wacana yang bukan aksara dapat dikategorikan sastra: sastra lisan. Sastra lisan adalah kesusastraan yang mencakup ekspresi kesusastraan warga suatu kebudayaan yang disebarkan dan diturun-temurunkan sastra lisan (dari mulut ke mulut), sedangkan sastra tulis berupa karya sastra yang dicetak atau ditulis. Keduanya, baik lisan maupun tulisan, tetap mengandung nilai sastra (nilai estetik). Sebagai bagian dari kebudayaan, sastra lisan tidak lepas dari pengaruh nilai-nilai yang hidup dan berkembang pada masyarakat. Dengan demikian, karya sastra bukanlah suatu karangan kosong atau khayalan yang sifatnya tidak sekadar menghibur pembaca 
Siwi Tri Purnani, Asal-usul Reog... (hlm. 243-250)

saja tetapi melalui karya sastra pembaca akan lebih memahami masalah kehidupan (Astika dan Yasa, 2014: 2).

Objek kajian karya sastra dapat berupa karya sastra tulis dan karya lisan. Karya sastra tulis adalah sastra yang teksnya berisi cerita yang ditulis atau dibukukan, sedangkan karya sastra lisan adalah cerita atau teks yang bersifat kelisanan dan diturunkan secara lisan dari generasi ke generasi berikutnya secara turun-menurun. Dalam sastra lisan akan didapatkan berbagai gambaran keadaan pola hidup masyarakat zaman dulu karena di manapun sastra diciptakan akan selalu merefleksikan pola hidup masyarakatnya. Melalui karya sastra, dapat dilihat gambaran kehidupan masyarakat pada saat sastra itu diciptakan. Oleh sebab itu, lebih tepat jika sastra itu dikatakan sebagai rekaman yang selalu mencerminkan kehidupan masyarakatnya (Zaidan, 2002:26). Sastra lisan merupakan salah satu bagian dari sastra daerah yang menjadi simbol atau identitas kebudayaan yang dimiliki oleh suatu daerah. Adanya sastra lisan, suatu daerah memiliki nilai tradisi yang ditinggalkan oleh para leluhur kepada generasi pewaris budaya.

Sastra lisan kadang ada yang murni dan ada juga yang tidak murni. Sastra lisan murni berupa dongeng, legenda, cerita yang tersebar secara lisan dari masyarakat. Sastra lisan tidak murni biasanya berbaur dengan tradisi lisan. Sastra lisan yang berbaur ini kadang hanya berupa penggalan cerita sakral, seperti cerita yang berasal dari tradisi leluhur yang tak utuh. Menurut Teeuw (1994:28), dalam sastra lisan tidak ada kemurnian sehingga penciptaannya selalu meniru kenyataan dan/atau meniru konvensi penciptaan sebelumnya yang sudah tersedia.

Menurut Hutomo (dalam Didipu, 2011:28), sastra lisan memiliki ciri-ciri berikut ini. (1) penyebarannya melalui mulut, maksudnya ekspresi budaya yang disebarkan, baik dari segi waktu maupun ruang melalui mulut, (2) lahir di dalam masyarakat yang masih bercorak desa, masyarakat di luar kota, atau masyarakat yang belum mengenal huruf, (3) menggambarkan ciri budaya suatu masyarakat, 
sebab sastra daerah merupakan warisan budaya yang menggambarkan masa lampau, tetapi menyebut pula hal-hal baru (sesuai dengan perubahan sosial), (4) tidak diketahui siapa pengarangnya sehingga menjadi milik masyarakat, (5) bercorak puitis, teratur dan berulang-ulang, (6) tidak mementingkan fakta dan kebenaran, (7) terdiri dari berbagai versi, dan (8) umumnya menggunakan gaya bahasa lisan (sehari-hari).

Reog Ponorogo merupakan salah satu bentuk folklor yang di dalamnya terdapat sastra lisan, yakni cerita rakyat atau mitos asal-usul Reog Ponorogo. Cerita rakyat ini berkembang secara turun-temurun dan diwariskan melalui lisan. Akan tetapi, karena penyebarannya yang dilakukan secara lisan sehingga terkadang cerita ini mengalami perubahan versi. Berbagai cerita tentang asal-usul Reog berkembang di masyarakat hingga saat ini.

\section{Asal-Usul Reog Sebagai Sastra Lisan Sindiran Birokrasi}

Berbicara mengenai sastra lisan, pasti selalu dikaitkan dengan istilah folklor. Folklor merupakan khazanah sastra lama. Kata folklor berasal dari bahasa Inggris, yaitu folklore. Kata majemuk ini terdiri dari dua kata dasar folk dan lore. Secara etimologi, folk artinya kolektif, atau ciri-ciri pengenalan fisik atau kebudayaan yang sama dalam masyarakat, sedangkan lore merupakan tradisi dari folk. Menurut Dundes (dalam Danandjaja, 2002:2), folk sama artinya dengan kolektif, folk juga berarti sekelompok orang yang memiliki ciri-ciri pengenal fisik, sosial, dan kebudayaan sehingga dapat dibedakan dari kelompok-kelompok lainnya.

Menurut Teeuw (dalam Endraswara, 2011:151), sastra lisan masih terdapat di berbagai pelosok masyarakat. Sastra lisan yang terdapat di daerah terpencil/pelosok, biasanya lebih murni karena mereka belum mengenal teknologi dan juga buta aksara dibandingkan dengan sastra lisan yang berada di tengah masyarakat perkotaan yang justru malah hanya terdengar gaungnya saja 
dikarenakan mulai tergeser dengan kecanggihan teknologi dan pengaruh dari budaya luar.

Dilansir dari laman Wikipedia, ada lima versi cerita popular yang berkembang di masyarakat tentang asal-usul Reog Ponorogo. Akan tetapi, salah satu cerita yang paling terkenal adalah cerita tentang pemberontakan Ki Ageng Kutu, seorang abdi kerajaan pada masa Bhre Kertabhumi, Raja Majapahit terakhir yang berkuasa pada abad ke-15. Ki Ageng Kutu murka akan pengaruh kuat dari pihak istri raja Majapahit yang berasal dari Cina, selain itu juga murka kepada rajanya dalam pemerintahan yang korup, ia pun melihat bahwa kekuasaan Kerajaan Majapahit akan berakhir. Ia lalu meninggalkan sang raja dan mendirikan perguruan di mana ia mengajar seni bela diri kepada anak-anak muda, ilmu kekebalan diri dan ilmu kesempurnaan dengan harapan bahwa anak-anak muda ini akan menjadi bibit dari kebangkitan kerajaan Majapahit kembali. Sadar bahwa pasukannya terlalu kecil untuk melawan pasukan kerajaan maka pesan politis $\mathrm{Ki}$ Ageng Kutu disampaikan melalui pertunjukan seni Reog yang merupakan “sindiran” kepada Raja Kertabhumi dan kerajaannya. Pagelaran Reog menjadi cara Ki Ageng Kutu membangun perlawanan masyarakat lokal menggunakan kepopuleran Reog.

Pada pertunjukan Reog ditampilkan topeng berbentuk kepala singa yang dikenal sebagai "Singa Barong", raja hutan yang menjadi simbol untuk Kertabhumi, dan di atasnya ditancapkan bulu-bulu merak hingga menyerupai kipas raksasa yang menyimbolkan pengaruh kuat para rekan Cinanya yang mengatur dari atas segala gerak-geriknya. Jatilan, yang diperankan oleh kelompok penari gemblak yang menunggangi kuda-kudaan menjadi simbol kekuatan pasukan kerajaan Majapahit yang menjadi perbandingan kontras dengan kekuatan warok yang berada di balik topeng badut merah yang menjadi simbol untuk Ki Ageng Kutu, sendirian dan menopang berat topeng Singabarong yang mencapai 
lebih dari $50 \mathrm{~kg}$ hanya dengan menggunakan giginya. Kepopuleran Reog $\mathrm{Ki}$ Ageng Kutu akhirnya menyebabkan Bhre Kertabhumi mengambil tindakan dan menyerang perguruannya, pemberontakan oleh warok dengan cepat diatasi, dan perguruan dilarang untuk melanjutkan pengajaran akan warok. Namun muridmurid Ki Ageng Kutu tetap melanjutkannya secara diam-diam. Walaupun begitu, kesenian Reog masih diperbolehkan untuk dipentaskan karena sudah menjadi pertunjukan popular di antara masyarakat, namun jalan ceritanya memiliki alur baru.

\section{SIMPULAN}

Awal mula perkembangan sastra dimulai dari sastra lisan lalu ke sastra tulisan karena manusia terlebih dahulu mengenal lisan daripada tulisan. Akan tetapi, keberadaan sastra lisan semakin lama semakin tidak dikenal karena penyebarannya yang dilakukan melalui lisan. Sastra lisan merupakan salah satu bagian dari sastra daerah yang menjadi simbol atau identitas kebudayaan yang dimiliki oleh suatu daerah. Adanya sastra lisan, suatu daerah memiliki nilai tradisi yang ditinggalkan oleh para leluhur kepada generasi pewaris budaya. Salah satu jenis cerita rakyat adalah cerita tentang asal-usul Reog Ponorogo. Salah satu cerita asal-usul Reog Ponorogo yang paling terkenal adalah cerita tentang pemberontakan Ki Ageng Kutu, seorang abdi kerajaan pada masa Bhre Kertabhumi, Raja Majapahit terakhir yang berkuasa pada abad ke-15. Ki Ageng Kutu murka akan pengaruh kuat dari pihak istri raja Majapahit yang berasal dari Cina, selain itu juga murka kepada rajanya dalam pemerintahan yang korup, ia pun melihat bahwa kekuasaan Kerajaan Majapahit akan berakhir. Dalam pertunjukan Reog ditampilkan topeng berbentuk kepala singa yang dikenal sebagai "Singa Barong", raja hutan yang menjadi simbol untuk Kertabhumi, dan di atasnya ditancapkan bulu-bulu merak hingga menyerupai kipas raksasa yang menyimbolkan pengaruh kuat para rekan Cinanya yang mengatur dari atas segala 
gerak-geriknya. Jatilan, yang diperankan oleh kelompok penari gemblak yang menunggangi kuda-kudaan menjadi simbol kekuatan pasukan kerajaan Majapahit yang menjadi perbandingan kontras dengan kekuatan warok yang berada di balik topeng badut merah yang menjadi simbol untuk Ki Ageng Kutu, sendirian dan menopang berat topeng Singabarong yang mencapai lebih dari $50 \mathrm{~kg}$ hanya dengan menggunakan giginya. Kepopuleran Reog Ki Ageng Kutu akhirnya menyebabkan Bhre Kertabhumi mengambil tindakan dan menyerang perguruannya, pemberontakan oleh warok dengan cepat diatasi, dan perguruan dilarang untuk melanjutkan pengajaran akan warok. Namun murid-murid Ki Ageng Kutu tetap melanjutkannya secara diam-diam. Cerita tersebut menyiratkan bentuk sindiran seseorang terhadap pemimpinnya. Sindiran tersebut dilakukan karena pemerintahan yang dipimpin tidak berjalan sesuai dengan seharusnya. Hal ini diperkirakan terjadi pada jaman dahulu, pada masa Bhre Kertabhumi berkuasa sebagai Raja Majapahit.

\section{DAFTAR PUSTAKA}

Astika, I Made \& Yasa, I Nyoman. 2014. Sastra Lisan (Teori dan Penerapannya). Yogyakarta: Graha Ilmu.

Danandjaja, James. 2002. Folklor Indonesia: Ilmu Gosip, Dongeng, dan Lainlain. Jakarta: Grafitti.

Didipu, Herman. 2011. Sastra Daerah: Konsep Dasar dan Ancangan Penelitiannya. Gorontalo: Ideas Publishing.

Endraswara, Suwardi. 2011. Metodologi Penelitian Sastra. Yogyakarta: CAPS.

Taum, Yoseph Yapi. 2011. Studi Sastra Lisan: Sejarah, Teori, Metode, dan Pendekatan Disertai Contoh Penerapannya. Yogyakarta: Lamalera. 
PARAMASASTRA, Vol. 4, No. 2 -September 2017

Wikipedia. 2014. Reog (Ponorogo). (Online). (http://wikipedia.org/wiki/Reog_(Ponorogo).html). Diakses pada tanggal 1 Juli 2017.

Zaidan, Abdul Razak. 2002. Mitologi Jawa dalam Puisi Indonesia 1971-1990. Jakarta: Pusat Bahasa Depdiknas. 